The Chittagong Univ. J. B. Sci., Vol. 3(1 \&2): pp. 119-126, 2008.

\title{
LENGTH-WEIGHT RELATIONSHIP AND RELATIVE CONDITION FACTOR OF THE RIBBON FISH, LEPTURACANTHUS SAVALA (CUVIER, 1829) FROM THE BAY OF BENGAL, BANGLADESH
}

\author{
MOHAMMAD ALI AZADI* AND MOHAMMAD ULLAH \\ Department of Zoology, University of Chittagong, Chittagong 431, Bangladesh
}

\begin{abstract}
Length-weight relationship of 1119 specimens of Lepturacanthus savala (Cuvier 1829) from the Bay of Bengal, Bangladesh, was found to be curvilinear ( $\mathrm{W}=$ $\left.0.0003612 \mathrm{TL}^{3.18}\right)$ and linear $(\log \mathrm{W}=-3.44+3.18 \mathrm{LogTL})$ for both the sexes combined in arithmetic and logarithmic scales, respectively. The values of regression co-efficient (b) ranged from 3.002 to $3.337(\beta \pm 0.167)$ at $95 \%$ confidence limit. The regression ' $b$ ' value (3.18) followed the cube law and did not significantly $(\mathrm{P}>0.05)$ differ from the cube. The growth of the fish was found to be isometric. Relative condition factor $(K n)$ was also within the ideal range (0.9695 to 1.1155 , mean $1.001 \pm 0.033$ ). Seasonal or in different length groups no dramatic changes in relative condition factor were observed. Length frequency distribution was found to be normal with maximum number of fish in mid length groups and minimum in the lowest and highest length groups.
\end{abstract}

Key words:Length-weight relationship, Relative condition factor, Lepturacanthus savala, Bay of Bengal, Bangladesh.

\section{INTRODUCTION}

Analysis of length-weight relationship of the Ribbon fish, Lepturacanthus savala, was carried out to detect the physical well-being of the fish and to establish the fact whether the growth of the fish is isometric or not, because knowledge about the growth of fish is the most important part of the study of population dynamics and also for its cultural purposes. Relative condition factor $(K n)$ was also calculated to see whether the growth of the fish was ideal or not. The condition factor of the relationship (Le Cren 1951) was used as an useful index for assessment of various important biological and nutritional cycle, while the mathematical relation between the length and the weight has valuable use in estimating the weights of fish of known lengths or known weights. The lengthweight study of fishes gives an idea on the seasonal changes in their specific

\footnotetext{
* Corresponding Author E-mail: maazadi@yahoo.com
} 
gravity. A considerable number of works has been done on the length weight relationship and relative condition factor of different fish species in Bangladesh and India by different authors (Jhingran 1968, Basirullah and Kader 1970, Shafi and Quddus 1973, 1974a, 1974b, Chondar 1973, Chatterji et al. 1977, Das 1977, Kader and Rahman 1978, Quddus et al. 1987, Quddus and Dewan 1988, Barua et al. 1988, Azadi et al. 1988, Mahmood et al. 1989, Azadi and Nasiruddin 1990, Banu et al. 1992, Azadi et al. 1992, Azadi and Naser 1996, Nabi et al. 1999, Mamun and Azadi 2004, Azadi and Rahman 2007). Except two short works (Basirullah and Kader 1970, Mustafa and Begum 1994) no detailed work is available on the length-weight relationship and relative condition factor of Lepturacanthus savala from the Bay of Bengal.

\section{MATERIALS AND METHODS}

For the study of length-weight relationship and relative condition factor a total of 1119 specimens of $L$. savala were collected from the biggest Bay fishing landing station namely "Fishery Ghat" at Iqbal Road, Chittagong, Bangladesh, during March 2003 to February 2004. The total body length and weight of each fish was measured to the nearest centimeter and gram from the tip of the snout to the tail end of the body, and with a pan balance sensitive up to $0.1 \mathrm{~g}$, respectively. The length-weight relationship and relative condition factor $(K n)$ were derived using the widely known formula of Le Cren (1951). The Co-efficient of regression for $\mathrm{Y}$ (Weight) on $\mathrm{X}$ (Total length) was calculated by least square method. Monthly size frequency distribution was also analysed.

\section{RESULTS AND DISCUSSION}

\section{Length-weight relationship}

Total length varied between $27.1 \mathrm{~cm}$ and $106.4 \mathrm{~cm}$, and the weight between $15 \mathrm{~g}$ and $1230 \mathrm{~g}$. The length-weight relationship for both the sexes combined was found to be positive curvilinear $\left(\mathrm{W}=0.0003612 \mathrm{TL}^{3.18)}\right.$ and linear $(\log \mathrm{W}=-3.44+3.18 \mathrm{LogTL})$ in arithmetic and logarithmic scales, respectively (Figs.1a and 1b). The relationship was highly significant $(\mathrm{r}=0.996, \mathrm{t}=44.47$, groups $=17$ ) at $0.1 \%$. The regression coefficient ' $b$ ' value was 3.18 and ranged from 3.00 to $3.34(\beta \pm 0.167)$ at $95 \%$ confidence limit, and followed the cube law (P>0.05), which agreed with Martin (1949), Carlender (1969, 1977), Shafi and Quddus (1974a, 1974b), Rao (1983), Azadi et al.1992 and Nabi et al.(1999) in other fishes. According to Pauly (1984), the exponent b lies between 2.5 and 3.5, usually close to 3 . Thus, the growth of $L$ savala was found to be isometric and 
LENGTH-WEIGHT RELATIONSHIP \& RELATIVE CONDITION FACTOR OF LEPTURACANTHUS SAVALA

ideal in the Bay of Bengal, which indicated that a congenial environment existed in the Bay water for the fish. Earlier no detailed work on the length-weight relationship and relative condition of $L$. savala was done from the Bay of Bengal except some short works by Basirullah and Kader (1970) and Mustafa and Begum (1994). Basirullah and Kader (1970) found regression ' $b$ ' values less than 1.0 for male and 2.19 for female L. savala while Mustafa and Begum (1994) found 'b' values 1.9 for male and 2.004 for female $L$. savala, which were not acceptable. It might be due to very small and short sized data or data were collected or measured erroneously (Carlender 1969). The authors (Basirullah and Kader 1970) admitted that it might be due to the effect of preservative formalin which squeezed the fish and offered erroneous length measurement. Carlender (1969, 1977) has demonstrated from a large number of length-weight data, stemming from a wide variety of fishes, that values of ' $b$ ' $<2.5$ or $>3.5$ are generally based on a very small range of sizes or that such values of 'b' are most likely erroneous.

\section{Relative condition factor $(\mathrm{Kn})$}

Kn values of $L$. savala in different months and different length groups are shown in Figs. 2 and 3. The highest $K n$ value 1.1155 was found at 25 to $30 \mathrm{~cm}$ length group and lowest 0.9695 at 40 to $45 \mathrm{~cm}$ length group with a mean of 1.001 \pm 0.033 . Monthly highest $K n$ value was found in January 2004 (1.005 \pm 0.028$)$ and lowest in May $2003(0.998 \pm 0.014)$. In different months the fluctuations of $K n$ values were very negligible. The monthly mean $K n$ values were always around 1. Except for a slight variation in only one lowest size group $(25-30 \mathrm{~cm})$, no major variation was found in different length groups. It clearly indicated that the growth pattern of the fish was ideal in the Bay of Bengal. $K n$ values generally fluctuated with changing seasons, amount of food supply, and maturity of gonads (Doha and Dewan 1967, Basirullah and Kader 1970, Azadi and Barua 1999, Nabi et al. 1999). In the present study no such effect was observed on $K n$ values due to the ribbon shaped long body and gonads; no major effect was also resulted due to the maturity of the gonads.

\section{Size frequency distribution}

The highest number of fish frequency $(\Sigma \mathrm{f}=215)$ was observed in $70 \mathrm{~cm}$ to $75 \mathrm{~cm}$ length group and the lowest $(\Sigma \mathrm{f}=2)$ in $105 \mathrm{~cm}$ to $110 \mathrm{~cm}$ length group (Fig.4). However, the distribution was found to be normal with minimum numbers in lowest and highest length groups and maximum in mid length groups. Similar type of size frequency distribution was also recorded in other fishes by Mamun and Azadi (2004). 
AZADI \& ULLAH
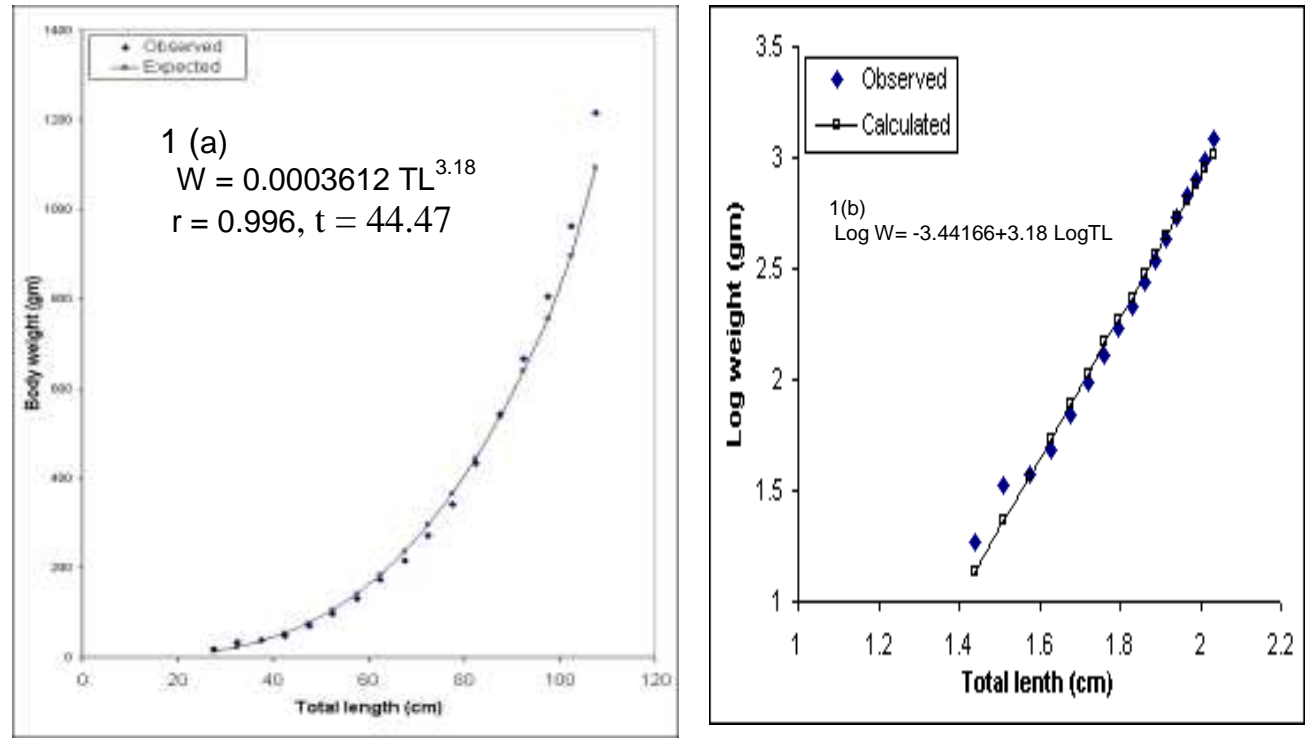

FIG.1. LENGTH-WEIGHT RELATIONSHIP OF L. SAVALA. IN ARITHMETIC (A) AND LOGARITHMIC SCALES (B).

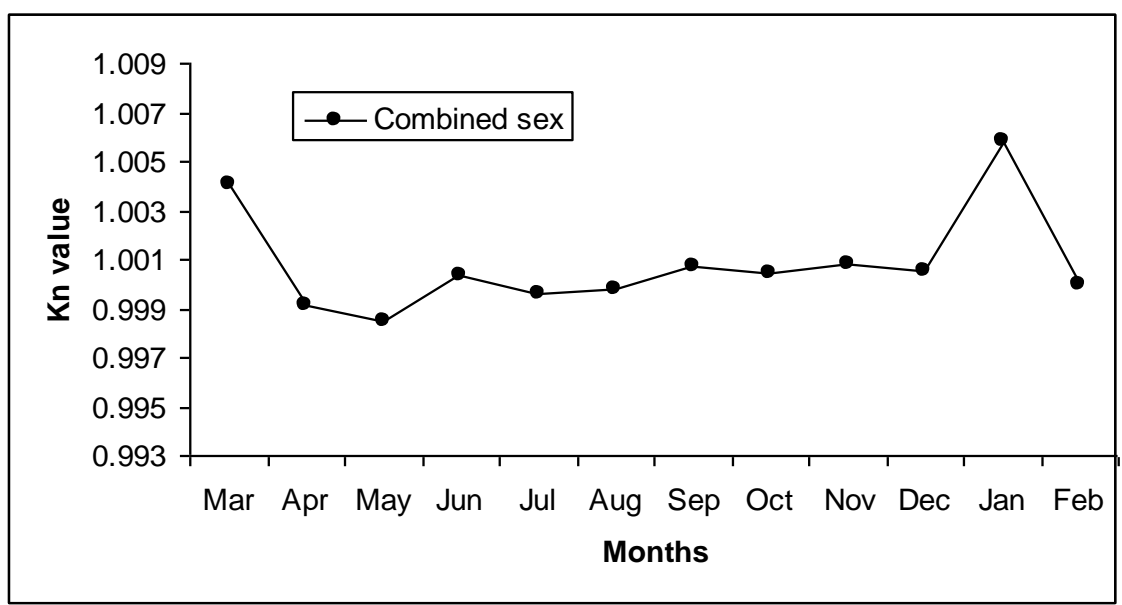

FIG. 2. RELATIVE CONDITION FACTOR $(K N)$ OF L. SAVALA IN DIFFERENT MONTHS. 
LENGTH-WEIGHT RELATIONSHIP \& RELATIVE CONDITION FACTOR OF LEPTURACANTHUS SAVALA

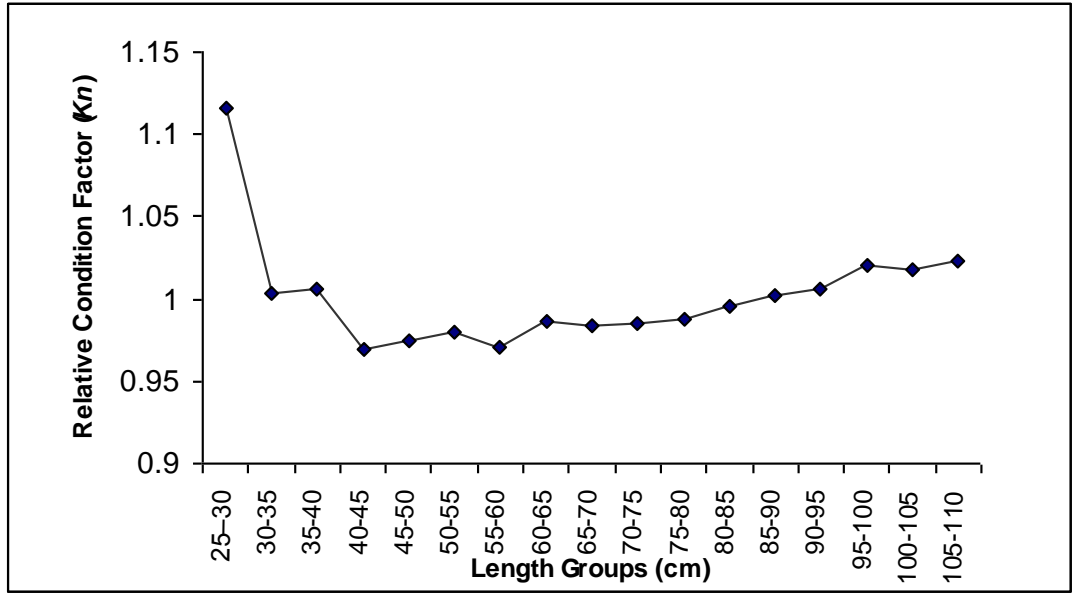

FIG. 3. RELATIVE CONDITION FACTOR (KN) OF L. SAVALA IN DIFFERENT LENGTH GROUPS

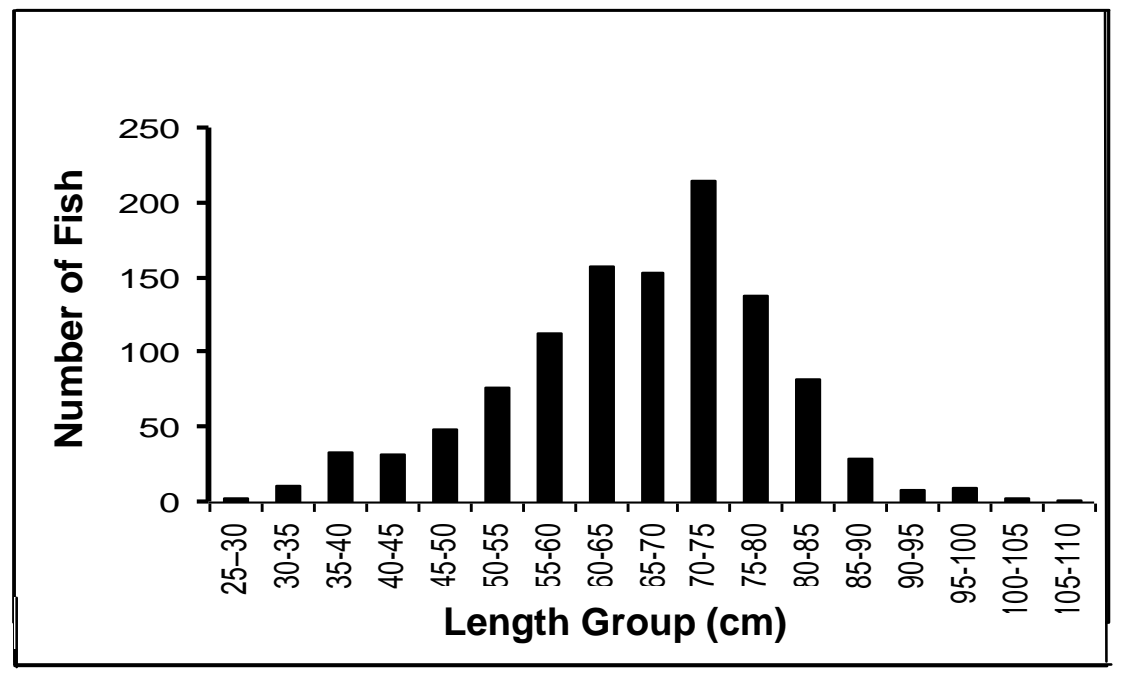

FIG. 4. SIZE FREQUENCY DISTRIBUTION OF L. SAVALA. 
AZADI \& ULLAH

\section{REFERENCES}

AZADI, M. A., ISLAM, M. A. AND SOLAIMAN, S. 1988. Length-weight and girth-weight relationship and relative condition in Eutropiichthys vacha from Kaptai reservoir, BAAS Abstract, section 11, 27p.

AZADI, M.A. AND NASIRUDDIN, M. 1990. Some aspects of biology of Oreochromis niloticus (Linn.) from Kaptai lake. Bangladesh J. Sci. Res. Special issue 59-68.

AZADI, M.A., ISLAM, M.A. AND PAUL, J.G. 1992. Biology and Fishery of the Catfish, Mystus aor in the Kaptai Reservoir, Bangladesh pp. 125140. In Reservoir Fisheries of Asia (De Silva, S.S. ed.). International Development Research Centre, Ottawa, Canada

AZADI, M. A. AND NASER, A. 1996. Length-weight relationship and relative condition factor of a carp, Labeo bata (Ham.) from Kaptai reservoir, Bangladesh. Chittagong Univ. Stud. Part II Sc. 20(2):19-25.

AZADI, M.A. AND RAHMAN, A.S.M.S. 2007. Length-weight relationship and relative condition factor of Gonialosa manmina (Hamilton) (Clupeidae:Clupeiformes) from the Kaptai lake. Chittagong Univ. J. Biol. Sci. (in press)

BANU, N., KHAN, S. AND ISLAM, A. 1992. Length-weight relationship and fecundity of Lepidocephalus guntea (Hamilton-Buchanon 1822). Bangladesh J. Zool. 20(1):169-175.

BARUA, G., ISLAM, M. A., MOLLAH, M. F. A., QUDDUS, M. A. AND ISLAM, M. A. 1988. Length-weight relationship and growth condition of Clarias batrachus (Linn.) in different months and sexes. Bangladesh J. Fish. 1(2):21-34.

BASHIRULLAH, A. K. M. AND KADER, M. A. 1970. The length weight relationship and condition factor of Trichiurus savala Cuv. Pak. J. Sci. In. Res. 13(4):4-419.

CARLENDER, K.D. 1969. Handbook of freshwater fishery biology (vol.I). Iowa State University Press, Ames, IA, USA.

CARLENDER, K.D. 1977. Handbook of freshwater fishery biology (vol.II). Iowa State University Press, Ames, IA, USA.

CHATTERJI, A., SIDDIQUE, A. Q. AND KHAN, A. A. 1977. Length-weight relationship of a carp, Labeo bata (Ham.) Proc. Indian Acad. Sci. 86B(3):189-194.

CHONDAR, S. L. 1973. Length-weight volume relationship of Gudusia chapra 
LENGTH-WEIGHT RELATIONSHIP \& RELATIVE CONDITION FACTOR OF LEPTURACANTHUS SAVALA

(Ham.) Proc. Indian Acad. Sci. 80B(3): 51-67.

DAS, H. P. 1977. Length-weight relationship and relative condition of grey mullet Mugil cephalus L. Mahasagar Bull. Nat. Inst. Ocean. 10 (3\&4): 145-149.

DOHA, S. AND DEWAN. S. 1967. Studies on the biology of tilapia, Tilapia mossambica (Peters). III. Length-weight relationship and condition factor. Pakistan J. Sci. 19: 14-23.

JHINGRAN, A. G. 1968. The length-weight relationship and kn factor of Gudusia chapra (Ham.) from the Ganga river system. Proc. Nat. Acad. Sci. India 30B (3 and 4):249-263.

KADER, M. A. AND RAHMAN, M. M. 1978. The length-weight relationship and condition factor of Tilapia mossumbicus. J. Asiatic Soc. Bangladesh, Sci. 3(2):1-17.

LE CREN, E. D. 1951. The length-weight relationship and seasonal cycle in gonad weight and condition in the Perch. Perca fluviatalis. J. Anim. Ecol. 20: 201-219.

MAHMOOD, M., JAFAR, M. AND DATTA, K. 1989. On the length-weight relationship of Alpheus lobidens De Haan. 1850 from the coast of Bangladesh. Chittagong Univ. Stud. Part 11, Sci. 13 (1):77-80.

MAMUN, A. AND AZADI, M.A. 2004. Length-weight relationship, relative condition factor and size frequency distribution of Amblypharyngodon mola (Hamilton) inhabiting Kaptai Reservoir, Bangladesh. Progres. Agric. 15(1):173-180.

MARTIN, W.R. 1949. The mechanics of environmental control of body form in fishes. University of Toronto Studies in Biology 58: 1-91.

MUSTAFA, M. G. AND BEGUM, M. 1994. Some aspects of the biology of the Ribbon Fish, Lepturacanthus savala Cuvier in the Bay of Bengal. Proc. Ninth Nat. Zool. Conf. Bangladesh, pp. 23-30.

NABI, M. R. U., KADER, M. A. AND HAKIM, M. A. 1999. Length-weight relationship and condition factor in the fish Polynemus paradiseus from the Bay of Bengal. The Chittagong Univ. J. Sci. 23(2): 87-91.

PAULY, D. 1984. Fish population dynamics in tropical waters: a manual for use with programmable calculators. ICLARM Studies and Reviews 8, 325 p. International Center for Living Aquatic Resources Management, Manila, Philippines.

QUDDUS, M. A., ALI, M. A. AND DEWAN, S. 1987. Population estimation and length-weight relationship of Labeo rohita. Bangladesh J. Fish. 10(1):5-12. 
AZADI \& ULLAH

QUDDUS, M. A. AND DEWAN, S. 1988. Studies on monthly growth Lengthweight relationship and conditon factor of Oreochromis niloticus (Linnaeus). Bangladesh J. Fish. 11(1):13-18

RAO, K.V.S. 1983. Maturation and spawning of lizard fishes (Saurida sp.) from the northwestern parts of Bay of Bengal. Indian J. Fish. 30(1):27-45.

SHAFI, M. AND QUDDUS, M. M. A. 1973. The length-weight and length-girth relationship and condition in the carp, Labeo nandina (HamiltonBuchanan). Bangladesh J. Biol. Agri. Sci. 2(2):34-37.

SHAFI, M. AND QUDDUS, M. M. A. 1974a. The length-weight relationship and condition in the carp, Cirhinna mrigala (Hamilton-Buchanan, 1822). Dhaka Univ. Stud. Pt. B. XXII (1):39-45.

SHAFI, M. AND QUDDUS, M. M. A. 1974b. The length-weight relationship and condition in the Catla catla (Hamilton-Buchanan, 1822). J. Asiatic Soc. Bangladesh, Sci. 2(2):133-145.

Manuscript received on 18.10.08; Accepted on 17.2. 09

The Chittagong University Journal of Biological Sciences, Vol. 3( 1 \& 2): pp.119-126, 2008. 